\title{
STUDI EKONOMI TEKNIK PEMBUATAN PERAHU CADIK JENIS BOTTOM GLASS DARI BAHAN FIBER GLASS UNTUK WISATA BAHARI DI KELURAHAN BANTEN KECAMATAN KASEMEN KOTA SERANG PROVINSI BANTEN
}

\author{
Sri Sulasminingsih ${ }^{1}$, Budiman Adi Setyawan², Amir Marasabessy ${ }^{3}$ \\ Program Studi Teknik Industri, Universitas Pembangunan Nasional "Veteran” Jakarta, Jakarta Selatan ${ }^{1}$ \\ Program Studi Teknik Perkapalan, Universitas Pembangunan Nasional “Veteran” Jakarta, Jakarta Selatan ${ }^{2} 3$ \\ email $^{1}$ : srisulasminingsih125@gmail.com
}

\begin{abstract}
The fishermen in Kasemen subdistrict are the traditional fishermen who depend on the stars in the sky for navigation in caching fishes at the ocean. So, they do not go to the ocean everyday. There are many days that they must stay at home. They have another skill besides the fishermen. That is a problem. A solution of this problem is producing a special boat for the ocean tourisme. The boat is katir boat that made from plastics and combine with the glass at the bottom to see the beautiful under water views. The fishermen could be the guide of the sea tourisme because this area is rich with life and under water views. For the first, study to calculate of the cost is to be done, make a design of katir boat with the glass on the bottom and steps of production with economy of engineering method. The results are if the fishermen have to make the boat (Katir) with a special type by themselves need a lot of cost Rp.11.500.000 by a boat (without the engine). If the owner of the boats want to make of Katir production from fiberglass with a glass on the bottom as a special type for the ocean tourisme make a lot of cost Rp.12.710.000 by a boat (without the engine) and get a Rp.1.110.000 profit after reduced by production cost Rp.11.600.000 by a boat. If the investors want to enter the bussiness of Katir industry seriously, the capital will be back (Break Event Point/BEP) on time of 4.5 years or after $10^{\text {th }}$ Katir production
\end{abstract}

Keywords: Katir, the sea tourisme, bottom glass, BEP

\section{PENDAHULUAN}

Kelurahan Banten yang telah dikenal sejak abad 16 memiliki sifat pantai yang landai, berlumpur sehingga mudah terabrasi oleh ombak. Demikian pula halnya dalam budaya, Masyarakat Kelurahan Banten Kecamatan Kasemen terdiri dari berbagai suku diantaranya Bugis, Madura, Jawa (Cirebon, Cilacap,Tegal dll.) dan Banten sendiri dengan bahasa sehari-hari bahasa Jawa Serang. Kelurahan Banten mempunyai pulau-pulau yang berjarak sekitar 3-4 kilometer dari Pelabuhan Karangantu dengan pemandangan bawah laut yang indah. Para wisatawan yang ingin menyaksikan pemandangan tersebut harus menyewa perahu ikan para nelayan dan untuk dapat melihat pemandangan bawah laut itu harus menyelam. Saat ini belum ada perahu yang didisain khusus untuk wisata bahari disana . Jika ada perahu yang didisain khusus yang bagian bawahnya diberi kaca sehingga tidak perlu menyelam untuk dapat menikmati pemandangan bawah laut tentunya akan banyak wisatawan yang datang kesana.

Para nelayan di Banten menghadapi masalah yang sama yaitu sebagian besar nelayan lokal masih menggunakan navigasi bintang-bintang di langit di dalam mencari ikan, sehingga tidak setiap hari dapat pergi mencari ikan di laut. Ada hari-hari tertentu dimana mereka harus tinggal di darat. Jika sedang berada di darat mereka tidak dapat alih profesi misalnya menjadi sopir angkot, buruh bangunan, pedagang dan sebagainya. Permasalahan lainnya adalah banyak para nelayan yang tidak mempunyai perahu sendiri. Mereka hanya menjadi pekerja bagi para juragan kapal. Pilihan hidupnya hanya satu yaitu mencari nafkah di laut.Mereka akan senang mendapat pekerjaan apapun asal berhubungan dengan laut. Oleh sebab itu dibutuhkan solusi yang bijak di dalam memecahkan permasalahan ini secara komprehensif yang membuat mereka merasa nyaman di dalam pekerjaannya.

\section{TINJAUAN PUSTAKA \\ Kapal atau perahu Cadik.}

Kapal atau perahu cadik adalah kapal/perahu yang dilengkapi dengan alat penyeimbang agar kapal/perahu menjadi stabil dan tidak tenggelam. Cadik adalah bagian dari perahu yang dipasang di 
luar lambung secara sejajar. Cadik dapat berupa batangan yang lebih sempit dari perahu sendiri yang terbuat dari bahan kayu, bambu atau fiberglass.Tujuannya adalah untuk menstabilkan perahu.

\section{Bahan Baku.}

\section{Fiberglass.}

Perahu yang terbuat dari bahan fiberglass disebut juga dengan perahu/kapal plastik, karena terbuat dari dua komponen utama yaitu fiberglass sebagai penguat dan resin plastik poliester sebagai bahan pengisi. Dua bahan yang memiliki karakter fisik yang berbeda tetapi dapat saling melengkapi sehingga dikenal dengan istilah fiberglass reinforcement plastic (FRP) (Fyson,1985).. Komponen penguat yang umum digunakan adalah,

\section{1) Chopped Strand Mat (CSM).}

Chopped Strand Mat atau Mat. Laminasi Chopped Strand Mat (CSM) ini digunakan sebagai lapisan pengikat antara supaya tidak mudah terkelupas maupun selip pada proses laminasi berikutnya. Juga sering dipakai sebagai laminasi awal dan akhir dengan tujuan bagian sisi tersebut menjadi rata. Chopped Strand Mat (CSM) yang digunakan untuk pembuatan $\mathrm{kapal} /$ perahu terdiri dari,

(1). Chopped Strand Mat $300\left(300 \mathrm{~g} / \mathrm{m}^{2}\right)$

(2). Chopped Strand Mat $450\left(450 \mathrm{~g} / \mathrm{m}^{2}\right)$

\section{Woven Roving (WR).}

Woven roving adalah serat penguat berupa filament yang berbentuk anyaman plat yang saling tegak lurus antara lusi dan pakannya. Woven roving dipakai sebagai laminasi utama akan menambah kekuatan tarik dan lengkung yang lebih tinggi daripada laminasi Mat.

Adapun jenis serat penguat gelas (roving) tersebut antara lain,

(1) Woven roving $400\left(400 \mathrm{~g} / \mathrm{m}^{2}\right)$

(2) Woven roving $600\left(600 \mathrm{~g} / \mathrm{m}^{2}\right)$

(3) Woven roving $800\left(800 \mathrm{~g} / \mathrm{m}^{2}\right)$

\section{Woven Cloth.}

Woven cloth adalah kain yang berasal dari serat gelas yang dipintal menjadi benang kemudian benang-benang itu ditenun menjadi kain.Woven cloth akan menambah ketebalan plat dan lebih ekonomis jika digunakan tersendiri.

Sifat fisik material fiberglass secara umum a.l :

(1) Tensile strength yang tinggi dan kestabilan ukuran, baik.

(2) Daya serap air yang rendah. Serat gelas bersifat hidrofob tapi karena berbentuk kain maka akan ada rongga diantara tenunan yang dapat dimasuki air.

(3) Tahan terhadap temperatur yang tinggi.

(4) Tidak mudah terbakar dan sifat konduktor listrik yang baik.
(5) Tidak akan membusuk, menjamur dan berkurang kualitasnya.

(6) Tanah terhadap minyak, asam dan hama yang merusak kain.

(7) Elongation tinggi pada elastic limit yield point dan break point sama.

Keuntungan memakai bahan fiberglass jika dibandingkan dengan bahan lainnya di dalam pembuatan perahu antara lain adalah:

1) Bahan baku banyak terdapat dimana saja dan setiap saat dapat dibeli.

2) Berat Perahu fiberglass lebih ringan dari pada perahu dari bahan lainnya.

3) Kekuatan perahu fiberglass mempunyai kekuatan kosntruksi yang cukup kuat.

4) Perahu fiberglass mempunyai ketahanan air laut yang sangat tinggi.

5) Koefisien gesek kapal fiberglass dengan air akan lebih kecil

6) Tampilan dan warna kapal fiberglass lebih menarik dan lebih mewah sehingga menarik orang untuk ingin memilikinya.

Sedangkan kelemahan kapal yang terbuat dari bahan fiberglass antara lain:

1) Kapal lebih mudah terbawa angin karena ringan.

2) Stabilitas kapal lebih buruk juga karena ringan.

3) Pada kapal ikan, tenaga untuk menarik peralatan penangkap ikan lebih lemah.

4) Diperlukan cara khusus untuk membuat kapal/perahu dari bahan fiberglass.

5) Bahan tidak cukup kuat jika bergesekan dengan peralatan penangkap ikan.

6) Bahan mudah terbakar.

\section{Resin.}

Resin merupakan material cair sebagai pengikat serat penguat yang memiliki kekuataan tarik serta kekakuan lebih rendah dibandingkan serat penguatnya.

Ada 5 (lima) jenis resin polyester, yaitu:

(1).Poliester (Orthophtalic). Contohnya Yukalac 157 BQTN-Ex

(2).Poliester (isophtalic).Contohnya Yukalac 150 HR-BQTN

(3).Epoxy.

(4).Vinyl Esterl.

(5).Resin Phenolic. Resin phenolic tahan asam dan alkali.

Resin yang biasa digunakan didalam industri kapal adalah jenis resin orthophtalic polyester (Yukalac 157 BQTN-Ex).

\section{Bahan Pendukung.}

(1).Katalis. Fungsi katalis adalah untuk memulai proses awal perubahan bentuk resin. Katalis yang 
biasa dipakai adalah Metyl Etyl Ketone Peroxide (MEKP).

(2).Akselerator.Akselerator adalah bahan pendukung yang berfungsi agar katalis dan resin polyester dapat berpolimerisasi pada suhu kamar dalam waktu yang lebih cepat. Dalam perdagangan ada akselerator yang telah dicampur dengan resin poliester yaitu resin SHCP 268 BQTN dan Yukalac 157 BQTN EX.

(3).Stiren. Stiren adalah cairan encer, bening yang berfungsi untuk mengencerkan.

(4).Gelcoat. Gelcoat berfungsi sebagai lapisan pelindung laminasi permukaan luar FRP dari gesekan benda keras. (Misalnya Gelcoat 2141 TEX).

(5).Pigmen/Pewarna. Pigmen berfungsi untuk memberikan warna pada lapisan luar yang dicampurkan dengan gelcoat. Misalnya Pigmen white super dsb.

(6).Parafin.Berfungsi memberikan kesan cerah pada gelcoat yang telah diberi pigmen.

(7).Lapisan pelepas (wax). Berfungsi untuk mencegah laminasi lengket dengan cetakan . Lapisan ini berada pada lapisan pertama sebelum gelcoat. Contohnya: Mirror glaze.

(8).Talek. Berfungsi sebagai dempul setelah dicampur dengan resin dan katalis.

\section{Lapisan Inti.}

Lapisan inti atau lapisan/bahan pengisi merupakan bahan-bahan yang digunakan untuk membentuk konstruksi fiberglass. Ada beberapa lapisan inti antara lain,

(1).Kayu/tripleks dll. Bahan pengisi yang biasa pada deck, sekat dan bangunan atas kapal.

(2).Pelat baja/besi.Pelat baja untuk pondasi dari mesin utama,mesin bantu, mesin geladak dan pelat mata (untuk mengangkat hasil laminasi misalnya lambung)

(3) .Pelat fiberglass.Pelat fiberglass dipakai sebagai siku/bracket dan sekat pada tangki bahan bakar, oli dan air (wash bulkhead).

(4).Firet Coremat. Firet Coremat sebagai pengganti mat maupun woven roving pada konstruksi yang menerima beban relatif rendah.

(5).Foamed Plastik.Foamed Plastik adaalah material yang berbentuk gabus. Foam plastik yang biasa dipakai adalah polystyrene, polyurethane dan polyvinyl chloride (PVC).

(5.1).Polystyrene menahan resapan air yang kurang baik, harganya paling murah.

(5.2).Polyurethane memiliki kemampuan yang lebih baik dibandingkan polystyrene. Dipakai pada gading-gading, pembujur pada lambung kapal.

(5.3).Polyvinyl Chloride (PVC) adalah foamed plastic yang memiliki keunggulan yang terbaik yaitu tahan terhadap pengaruh lingkungan korosif, ringan dan kemampuannya menahan resapan air sangat tinggi sehingga sangat cocok untuk bangunan kapal.
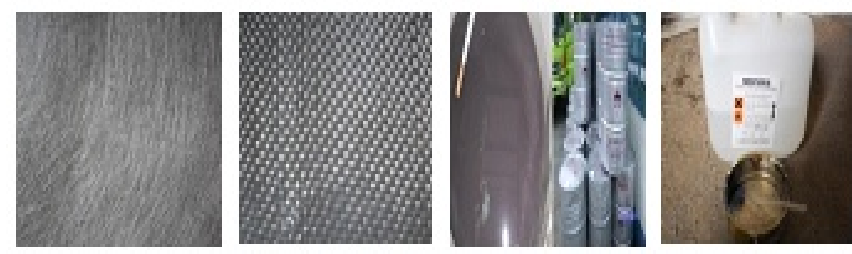

Choped strand mat

Woven roving
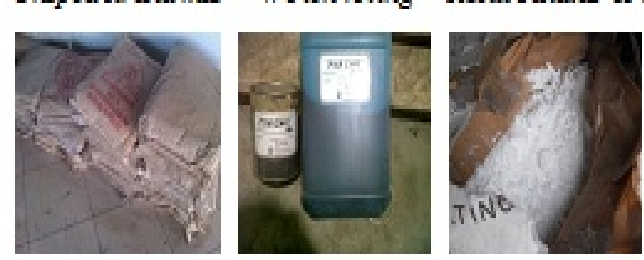

Katalis

Talk

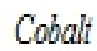

Herosil

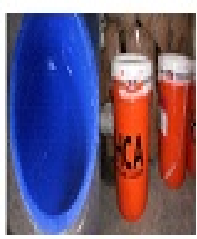

Gelcoat-

Gambar 1 Material fiberglass CSM dan WR serta bahan pendukungnya.

\section{Ekonomi Teknik Kapal.}

Ekonomi adalah ilmu tentang azas-azas produksi, distribusi dan pemakaian barang barang serta kekayaan (seperti hal keuangan,perindustrian dan perdagangan) ; pemanfaatan uang,tenaga,waktu dan sebagainya yang berharga; tata kehidupan perekonomian (suatu Negara); cakupan urusan keuangan rumah tangga (organisasi,Negara) (KBBI,2008).

Feyson (2010) menyatakan bahwa evaluasi ekonomi teknik merupakan prosedur paling penting dalam merancang kapal-kapal baru. Evaluasi ekonomi teknik dari kapal-kapal ikan membutuhkan suatu tim untuk bekerjasama seperti desainer, ekonomi perikanan, ilmuwan, operator dan investor. Langkah-langkah rencana kerja yang dapat ditempuh oleh desainer dan ekonomi perikanan menurut Feyson (2010) adalah sebagai berikut:

1) Pengumpulan data dari industri penangkapan yang sudah ada.

2) Mendefinisikan parameter-parameter desain dasar dari kapal-kapal baru.

3) Membuat gambar awal,daftar bahan dan alat yang dibutuhkan oleh kapal-kapal baru.

4) Menghitung biaya investasi.

5) Membandingkan keuntungan dari kapal-kapal dan

6) Menyelesaikan analisis dengan hati-hati.

\section{Biaya.}

Biaya produksi adalah biaya yang terjadi untuk mengolah bahan baku menjadi bahan setengah jadi atau produk jadi. Ada tujuh macam biaya produksi (Syamsudin et al., 2010): 
1) Biaya Tetap. Contoh biaya penyusutan, sewa gedung, pemasangan listrik dan telepon.

2) Biaya variable. Contohnya biaya bahan baku, biaya tenaga kerja langsung.

3) Biaya Total adalah semua biaya yang dikeluarkan untuk membuat barang.

4) Biaya tetap rata-rata adalah rata-rata biaya tetap yang dibebankan pada satu unit produksi.

5) Biaya tidak tetap rata-rata adalah rata-rata biaya tidak tetap yang dibebankan kepada satu unit produksi.

6) Biaya rata-rata adalah rata-rata biaya yang dibebankan kepada suatu unit produksi

7) Biaya Marginal adalah tambahan biaya per satu unit produksi.

Perancang kapal adalah seorang yang memiliki pengetahuan sempurna tentang seluruh macam komponen kapal yang tentu saja merupakan juru kunci untuk pembuatan perkiraan biaya. Dalam Bab Ekonomi Feyson (2009) menjelaskan pada desain kapal ikan biaya awal kapal biasanya jauh melebihi biaya bagian terbesar pada perhitungan cash flow karena banyak komponen-komponen biaya pelaksanaan/operasi maupun pendapatan dari operasi yang cenderung sangat terkait pada biaya investasi. Pada dasarnya teknologi pembuatan kapal untuk wisata sama dengan kapal ikan yang seukurannya hanya ada perubahan desain pada bagian tertentu tergantung penggunaannya. Adapun biaya-biaya yang dibutuhkan dalam produksi kapal cadik untuk wisata dapat dikelompokkan menjadi:

1) Biaya bahan baku (raw material cost) yaitu biaya untuk barang-barang yang dapat dengan mudah dan langsung diidentifikasikan dengan barang jadi.

2) Biaya buruh langsung (direct labour cost) adalah biaya untuk buruh yang menangani langsung proses produksi dan dapat diidentifikasikan langsung dengan barang jadi.

3) Biaya pabrik (overhead) adalah biaya-biaya pabrik, bahan baku dan buruh langsung.

\section{Cost per Cubic Number (CUNO)}

Cost per Cubic Number (CUNO) adalah cara yang paling baik untuk menghitung biaya pembuatan kapal berdasarkan ukuran kapal (LPP x B x D) Feyson (1985).Selain itu CUNO bisa dijadikan nilai patokan material oleh galangan kapal dalam pembuatan kapal tanpa harus menghitung satu demi satu unit material dan jenis-jenis biaya yang dibutuhkan.

\section{Kelayakan Usaha.}

Komponen yang digunakan dalam analisis usaha adalah penerimaan usaha, pengeluaran usaha dan pendapatan yang diperoleh dari usaha perikanan. Pendapatan/keuntungan adalah Penerimaan Total/Total Revenue (TR) dikurangi Biaya Total
(TC). Jika penerimaan total lebih besar dari biaya total maka usaha layak untuk dilanjutkan. Jika total penerimaan sama dengan total biaya maka usaha tidak untung dan tidak rugi , tapi jika total penerimaan lebih kecil dari total biaya maka usaha mengalami kerugian dan tidak layak untuk dilanjutkan.

Analisis R/C adalah analisis yang dipakai untuk mengetahui seberapa jauh setiap biaya yang digunakan bisa memberikan nilai penerimaan sebagai manfaat. Jika R/C lebih besar dari 1 (satu) maka kegiatan usaha tersebut untung sehingga layak dilanjutkan. Jika R/C sama dengan 1 (satu) maka kegiatan usaha tersebut tidak untung/rugi (impas), tapi jika R/C lebih kecil dari 1 (satu) berarti usaha tersebut rugi dan tidak layak dilanjutkan.

Payback periode merupakan suatu periode yang diperlukan untuk menutup kembali pengeluaran investasi (initial cash investment) dengan menggunakan aliran kas.

Break Even Point (BEP) adalah suatu alat analisis yang digunakan untuk mengetahui hubungan antar beberapa variabel di dalam kegiatan perusahaan (Umar, 2010)

\section{METODOLOGI}

Metoda penelitian yang digunakan adalah metoda penelitian studi kasus. Metoda studi kasus merupakan suatu metoda penelitian yang mempelajari secara intensif latar belakang serta interaksi lingkungan dari unit yang menjadi subyek; Hasilnya merupakan suatu generalisasi dari pola-pola kasus yang tipikal. Ruang lingkupnya bias bagian/segmen atau keseluruhan siklus/aspek. Penelitian ini lebih ditekankan pada pengkajian variabel yang

cukup banyak pada jumlah unit yang kecil . Didukung dengan studi literatur atau studi kepustakaan berdasarkan pengalaman kajian kepustakaan berupa data dan angka sehingga realitasnya dapat dipahami dengan baik.

Adapun tujuan dari penelitian studi kasus ini adalah untuk memberikan gambaran secara detail tentang latar belakang, sifat, karakteristik yang khas dari kasus yang kemudian dijadikan suatu hal yang bersifat umum.

\section{Waktu dan Tempat Penelitian.}

Penelitian akan dilaksanakan selama 6 bulan, mulai bulan Mei sampai dengan Oktober 2017. Lokasinya di beberapa tempat yaitu di Kelurahan Banten Kecamatan Kasemen Kota Serang Provinsi Banten, CV.Cisaanggarung Jakarta, Lab.Polimer Teknik Perkapalan dan Laboratorium Komputer FT. UPN 'Veteran” Jakarta.

\section{Teknik Pengumpulan Data.}

\section{1) Penelitian Lapangan (Field Research)}

Penelitian lapangan adalah penelitian yang dilakukan langsung pada proses pembuatan kapal 
cadik dari fiberglass. Pengumpulan data diperoleh melalui,

(1).Observasi.Observasi adalah suatu teknik pengumpulan data dengan mengamati langsung objek penelitian yang meliputi,

a. Pengukuran demensi utama kapal yang akan dibangun

b. Prosedur atau tahapan kerja dalam membangun kapal dan

c. Kebutuhan bahan baku dan bahan pembantu yang digunakan konstruksi kapal serta harga tiap satuan yang dibutuhkan dalam membangun kapal.

(2).Kuisioner.Kuisioner yaitu pengumpulan data dengan cara membuat pertanyaan yang diajukan kepada pihak-pihak yang terkait dengan masalah yang diteliti yang meliputi,

a. Biaya sewa galangan kapal (jika ada).

b. Biaya tenaga kerja dan

c. Biaya mesin dan perlengkapannya serta harga persatuan unit yang dibutuhkan

\section{2).Penelitian Kepustakaan (Library Research).}

Penelitian kepustakaan yaitu cara pengumpulan data berdasarkan literatur, majalah, artikel dll. Untuk memperoleh dasar teoritis dalam pemecahan masalah yang diteliti.Data literatur berguna sebagai bahan pertimbangan atas data yang diperoleh dari penelitian.

Data yang diperoleh akan diolah, dianalisis dan diproses lebih lanjut dengan dasar-dasar teori yang akhirnya akan diperoleh kesimpulan.

Langkah-langkah dalam pengukuran kapal untuk mendapatkan dimensi kapal, sbb. :

(1).Kapal yang akan diukur diatur kedudukannya hingga tepat pada posisi datar /rata air dengan memakai waterpass yang diletakkan pada bagian lunas dan lebar badan kapal.

(2).Kayu yang diletakkan pada ujung haluan dan buritan kapal dipakai sebagai tempat terbentangnya tali/benang. Tali ini diatur hingga letaknya berada diatas garis pusat longitudinal kapal. Kemudian panjang tali diukur sebagai panjang Loa.

(3).Breadth kapal diukur pada bagian kapal paling terlebar diukur dari sisi luar kapal yang satu ke sisi kapal yang lainnya.

(4).Depth diukur mulai dari dek terendah hingga ke bagian badan kapal terendah.

\section{Pengolahan Data \\ Perhitungan Gross Tonnage Kapal (GT)}

Gross Tonnage (GT) adalah volume ruang di bawah dan di atas dek. Berdasarkan keputusan Direktur Jenderal Perhubungan Laut Nomor: PY.67/I/16-02 dalam penentuan Gross Tonnage Kapal di Indonesia yaitu:

$$
\mathrm{GT}=0,25 \times \mathrm{V}
$$

$$
\mathrm{V}=\mathrm{a}+\mathrm{b}
$$

$\mathrm{a}=\mathrm{p} \times \mathrm{l} \times \mathrm{t}$

$\mathrm{b}=\mathrm{L}$ dek $\mathrm{x}$ Bmaks $\mathrm{x} \mathrm{D} \times \mathrm{f}$

Keterangan:

GT: Gross Tonnage (Ton)

0,25: Koefisien K1 yang nilainya tetap

$\mathrm{V}$ : Isi semua ruang tertutup

a: Volume ruang di atas dek

b: Volume ruang di bawah dek

p: panjang ruang

B: Volume ruang di bawah dek

L dek: Panjang dek kapal

Bmaks: Lebar badan kapal terlebar dari midship

D: Dalam kapal diukur dari atas dek sampai garis atas

F: 0,55 ((Keputusan Ditjen Perla Nomor : PY.67/1/16-02)

\section{Analisa Ekonomi Pembuatan Kapal.}

Dalam analisa ekonomi pembuatan kapal cadik untuk wisata bahari dibagi menjadi 2 (dua) pendekatan yaitu biaya operasional yang dikeluarkan oleh pengguna kapal dan penerimaan/upah/ongkos yang diperoleh pembuat/tukang kapal.

1).Biaya Operasional yang dikeluarkan oleh Pengguna.

Perhitungan biaya operasional pembuatan kapal cadik untuk wisata bahari dari bahan fiberglass yang dikeluarkan oleh pengguna adalah:

a) Biaya pembuatan kapal meliputi biaya upah tenaga kerja per unit kapal.

b) Biaya material meliputi biaya pembelian resin,kayu dan bahan pendukung lain dalam proses pembuatan per unit kapal , dan

c) Biaya pembelian mesin per unit kapal

Perhitungan biaya produksi kapal dilakukan memakai rumus seperti berikut ini,

$$
\begin{aligned}
& \mathrm{Y}=\mathrm{F}(\mathrm{X}) \text {. } \\
& \mathrm{Y}=\mathrm{X} 1+\mathrm{X} 2+\ldots \ldots+\mathrm{Xn}
\end{aligned}
$$

Keterangan:

Y: Biaya total produksi kapal

$\mathrm{X}$ : Faktor-faktor penentu biaya pembangunan kapal

2).Penerimaan Pembuat/Tukang Kapal

Upah bagi pembuat kapal diberikan berdasarkan kesepakatan kedua belah pihak.

\section{Biaya per Cubic Number (CUNO).}

Perhitungan CUNO (cubic Number)

berdasarkian Fyson (2005):

$$
\text { CUNO = Lpp X Bmax x D ..... (6) }
$$

\section{Keterangan:}

Lpp: Panjang kapal yang diukur antara garis tegak lurus pada perpotongan sarat air di bagian haluan dan buritan.

Bmaks: Lebar kapal terlebar yang diukur dari sisi luar kapal yang satu ke sisi lainnya. 
D: Dalam atau tinggi kapal yang diukur mulai dari dek terendah hingga bagian badan kapal terbawah/badan kapal tepat berada di atas lunas.

Perhitungan ekonomi teknik kapal dilakukan dengan menghitung biaya per ukuran CUNO kapal sebagai berikut:

$$
\text { Biaya/CUNO }=\text { Rp.........../m³ } \ldots .(7)
$$

Analisis Usaha.

Analisis usaha digunakan untuk mengevaluasi usaha yang dijalankan dan bertujuan untuk membantu perbaikan pengelolaan usaha. Analisis usaha dapat memberikan masukan untuk mengukur keberhasilan suatu usaha. Pengukuran analisis meliputi:

\section{1).Keuntungan $(\pi)$}

Keuntungan adalah jumlah nominal yang diperoleh dari selisih antara total pemasukan dengan total pengeluaran. Analisis ini bertujuan untuk mengukur apakah kegiatan usaha yang dilakukan berhasil atau tidak dan dapat juga untuk mengetahui keuntungan yang diperoleh dari suatu kegiatan usaha (Umar, 2003). Rumus yang digunakan adalah:

$$
\pi=\mathrm{TR}-\mathrm{TC}
$$

Keterangan:

$\pi$ : Keuntungan

TR: Total Penerimaan

TC: Total Biaya

Kriteria:

Jika Total Penerimaan $>$ Total Biaya, usaha untung/layak dilanjutkan

Jika Total Penerimaan = Total biaya, usaha tidak untung/rugi (impas)

Jika Total Penerimaan < Total Biaya, usaha rugi/tidak layak dilanjutkan

\section{Revenue Cost Ratio (R/C Ratio).}

Analisis ini dilakukan untuk mengetahui sejauh mana hasil yang diperoleh dari kegiatan usaha selama periode tertentu cukup menguntungkan (Umar, 2003)

Rumus yang digunakan adalah:

$$
R / C: \frac{T R}{T C}
$$

Kriteria:

Jika R/C > 1, maka kegiatan usaha tersebut untung sehingga layak dilanjutkan.

Jika $\mathrm{R} / \mathrm{C}=1$, maka kegiatan usaha tersebut impas/tidak untung dan tidak rugi

Jika $\mathrm{R} / \mathrm{C}<1$, maka kegiatan usaha tersebut rugi/tidak layak dilanjutkan.

\section{Payback Periode (PP).}

Payback Periode adalah periode yang diperlukan untuk menutup kembali pengeluaran investasi (initial cash investment) dengan memakai aliran kas. Payback Periode dapat pula diartikan sebagai ratio antara initial cash investment dengan cash inflow yang hasilnya merupakan satuan waktu. Kemudian nilai ratio dibandingkan dengan maksimum payback periode yang dapat diterima. Rumus yang digunakan (Umar, 2003) adalah:

$P P=\frac{i+\text { biaya produksi awal tahun }}{\text { Keuntungan }(\pi)} \times 1$ tahun

\section{Break Event Point (BEP)}

Break Event Point menggambarkan volume produksi pada titik impas usaha. Pada titik ini usaha tak mengalami keuntungan/kerugian (Gasperz, 1992). Rumus menghitung BEP:

$$
\begin{aligned}
& B E P(\text { Biaya })=\frac{\text { Biaya Tetap }}{1-\frac{\text { Biaya Variabel }}{\text { Hasil Penjualan }}} \ldots . . . . . .(11) \\
& B E P(\text { Unit })=\frac{\text { Biaya Tetap x Jumlah produksi }}{\text { Penerimaan Bersih }} . .
\end{aligned}
$$

\section{SURVAI LAPANGAN DAN STUDI PUSTAKA}

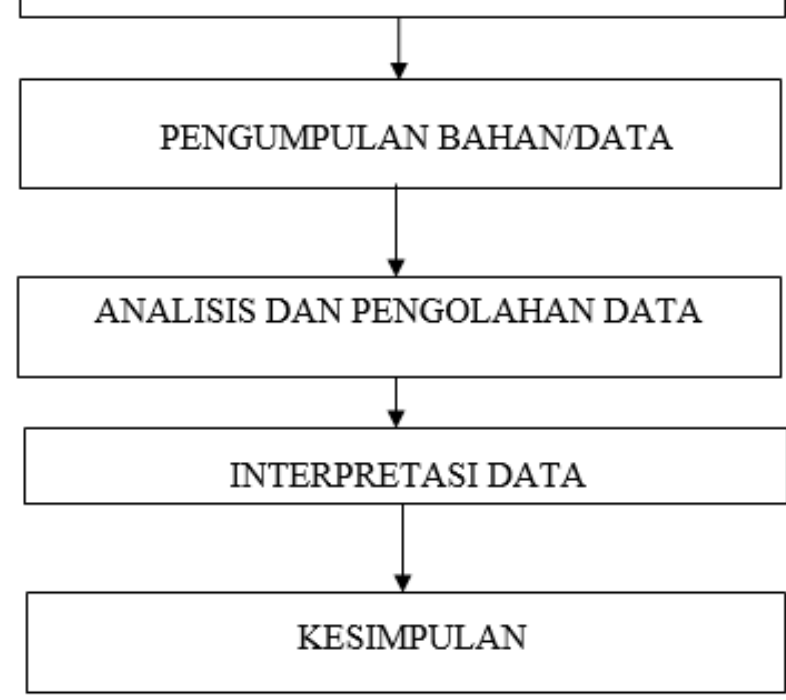

Gambar 2 Diagram Alir Penelitian

\section{HASIL DAN LUARAN YANG DICAPAI. Disain dan dimensi Perahu Cadik Wisata tipe Bottom Glass.}

Disain perahu dilakukan untuk mengestimasi biaya yang diperlukan dalam pembuatan perahu cadik wisata tipe bottom glass yang terbuat dari bahan e-glass dari mulai rancangan umum sampai dengan hal yang lebih rinci seperti penempatan daun kemudi, pemasangan ruang ballast dll.Biasanya pembuatan disain perahu berpatokan pada perahu yang telah ada di lokasi untuk memudahkan dan menandakan wilayah/kelompok perahu itu berasal. 


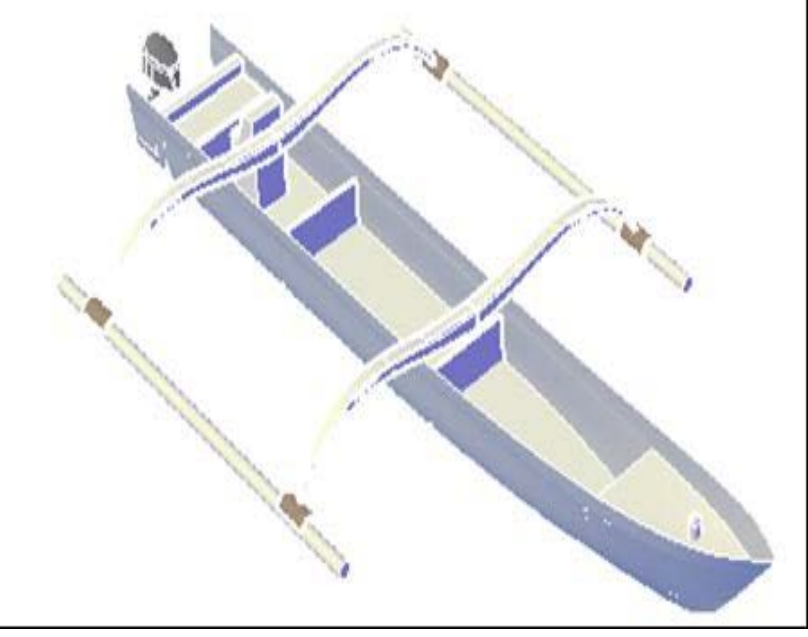

Gambar 3 Rancangan Perahu Cadik untuk Wisata Bahari

Dimensi utama dari perahu cadik tipe bottom glass meliputi panjang (L), lebar (B) dan dalam perahu (D) dimana ketiga faktor tersebut akan mempengaruhi kelayakan perahu.

LOA: $10.0 \mathrm{~m}$

B: $1.2 \mathrm{~m}$

D: $0.8 \mathrm{~m}$

LPP: $8.7 \mathrm{~m}$

CUNO: $8.35 \mathrm{~m}^{3}$

Kapasitas Angkut: 3 orang

Kapasitas Muat: $1.5 \mathrm{~m}^{3}$ (+/- $\left.500 \mathrm{Kg}\right)$

Gross Tonnage: 1

OBM: 15-25 PK V= 7-8 knot

Hasil.

Adapun data dan hasil perhitungan kajian ekonomi teknik pembuatan perahu cadik tipe bottom glass untk wisata bahari di Kelurahan Banten adalah sbb:

Tabel 4. Biaya Pembuatan Perahu Cadik Tipe Bottom Glass untuk Wisata Bahari di Kelurahan Banten Kota Serang Provinsi Banten pada tahun 2017.

\begin{tabular}{|l|l|r|}
\hline No. & Pekerjaan & Biaya (Rp) \\
\hline 1 & Mould/Cetakan & 5.000 .000 \\
\hline 2 & $\begin{array}{l}\text { Material Fiberglass dan } \\
\text { finishing cat }\end{array}$ & 7.500 .000 \\
\hline 3 & $\begin{array}{l}\text { Peralatan Kerja } \\
\text { Fiberglass }\end{array}$ & 1.500 .000 \\
\hline 4 & Perlengkapan Kapal & 7.000 .000 \\
\hline 5 & Biaya Lain-lain & 5.000 .000 \\
\hline 6 & Jumlah & 26.000 .000 \\
\hline
\end{tabular}

\section{Pembahasan.}

Tekno ekonomi Perahu Cadik tipe Bottom Glass untuk WIsata Bahari.
Biaya yang harus dikeluarkan kan untuk pembuatan sebuah perahu cadik tipe bottom glass khusus wisata bahari Loa 10 meter untuk pembuatan pertama sekitar Rp.26.000.000,- per buah. Untuk pembuatan ke dua, ke tiga dan seterusnya hanya Rp.21.000.000,- karena cetakan perahu atau moulded yang dibuat bersifat permanen. Cetakan hanya dibuat pada awal investasi . Jadi untuk selanjutnya tidak perlu lagi membuat cetakan.

Adapun rincian biaya yang diperlukan seperti terlihat pada table berikut ini.

Tabel 5. Biaya Produksi Perahu Cadik Tipe Bottom Glass Untuk Wisata Bahari Panjang 10 Meter.

\begin{tabular}{|r|l|r|r|}
\hline No. & KETERANGAN & $\begin{array}{l}\text { BIAYA } \\
\text { (Rp) }\end{array}$ & \%TASE \\
\hline 1 & Upah & 2.100 .000 & 12.65 \\
\hline 2 & Biaya Material & 9.000 .000 & 54.22 \\
\hline 3 & Transportasi & 500.000 & 3.01 \\
\hline 4 & $\begin{array}{l}\text { Pembelian Mesin 9 } \\
\text { PK }\end{array}$ & 5.000 .000 & 30.12 \\
\hline \multicolumn{2}{|r}{ Jumlah } & 16.600 .000 & 100.00 \\
\hline
\end{tabular}

Biaya total produksi adalah sebesar Rp.16.600.000,- per buah yang merupakan biaya yang dikeluarkan dalam pembangunan perahu. Biaya yang terbesar adalah biaya Material

Tabel 6. Biaya yang dikeluarkan Pembuatan Perahu Cadik Tipe Bottom Glass untuk Wisata Bahari (Keseluruhan)

\begin{tabular}{|c|l|c|r|}
\hline No. & KETERANGAN & $\begin{array}{l}\text { BIAYA } \\
\text { (Rp) }\end{array}$ & \%TASE \\
\hline 1 & $\begin{array}{l}\text { Cetakan/ } \\
\text { moulded }\end{array}$ & 5.000 .000 & 19,23 \\
\hline 2 & $\begin{array}{l}\text { Material \& } \\
\text { Peralatan }\end{array}$ & 9.000 .000 & 34,62 \\
\hline 3 & $\begin{array}{l}\text { Perlengkapan } \\
\text { Perahu }\end{array}$ & 7.000 .000 & 26,92 \\
\hline 4 & Lain-lain & 5.000 .000 & 19,23 \\
\hline \multicolumn{2}{|l|}{ Jumlah Keseluruhan } & 26.000 .000 & 100.00 \\
\hline
\end{tabular}

Berdasarkan Tabel 5 diatas , biaya yang dibutuhkan untuk membangun sebuah perahu cadik tipe bottom glass untuk wisata bahari dari bahan e-glass dengan ukuran panjang 10 meter di Kelurahan Banten pada saat pertama kali sebesar Rp.26.000.000,- per buah. Untuk selanjutnya hanya Rp.21.000.000,- per buah dengan ukuran perahu .Biaya yang terbesar adalah biaya material pokok dan peralatan kerja/pembuatan perahu sebesar Rp.9.000.000,-. 
Tabel dibawah ini adalah menerangkan tentang perhitungan persentase biaya pembangunan dan keuntungan terhadap biaya total produksi.

Tabel 7. Prosentase Biaya Produksi Dan Keuntungan Terhadap Biaya Total Produksi Perahu Cadik Bottom Glass

\begin{tabular}{|c|c|c|}
\hline No. & URAIAN & KET. \\
\hline 1 & $\begin{array}{l}\text { Dimensi Perahu CUNO } \\
8.35 \mathrm{~m}^{3}\end{array}$ & - \\
\hline 2 & $\begin{array}{l}\text { Biaya Material Pokok e- } \\
\text { glass }\end{array}$ & 7.500 .000 \\
\hline 3 & $\begin{array}{l}\text { Biaya Material non e- } \\
\text { glass }\end{array}$ & 1.500 .000 \\
\hline 4 & Transportasi & 500.000 \\
\hline 5 & Upah & 2.100 .000 \\
\hline 6 & $\begin{array}{l}\text { Biaya Total Produksi } \\
(2+3+4+5)\end{array}$ & 11.600 .000 \\
\hline 7 & $\begin{array}{l}\text { Biaya Total Produksi } \\
\text { CUNO Rp. } / \mathrm{m}^{3}\end{array}$ & $1.389 .221,5$ \\
\hline 8 & $\begin{array}{l}\text { Harga Jual } \\
(6+10 \%(5+2))\end{array}$ & 12.710 .000 \\
\hline 9 & Keuntungan (12-6) & 1.110 .000 \\
\hline 10 & $\begin{array}{l}\text { \% tase total material } \\
\text { terhadap biaya total } \\
\text { produksi }\end{array}$ & 77.6 \\
\hline 11 & $\begin{array}{l}\text { \% tase total material } \\
\text { terhadap harga jual }\end{array}$ & 70.8 \\
\hline 12 & $\begin{array}{l}\text { \% tase biaya transportasi } \\
\text { terhadap biaya total } \\
\text { produksi }\end{array}$ & 4.31 \\
\hline 13 & $\begin{array}{l}\text { \% tase biaya transportasi } \\
\text { terhadap harga jual }\end{array}$ & 3.93 \\
\hline 14 & $\begin{array}{l}\text { \% tase upah terhadap } \\
\text { biaya total produksi }\end{array}$ & 18.1 \\
\hline 15 & $\begin{array}{l}\text { \% tase upah terhadap } \\
\text { harga jual }\end{array}$ & 16.5 \\
\hline 16 & $\begin{array}{l}\text { \% tase keuntungan } \\
\text { terhadap biaya produksi }\end{array}$ & 9.57 \\
\hline 17 & $\begin{array}{l}\text { \% tase keuntungan } \\
\text { terhadap harga jual }\end{array}$ & 8.73 \\
\hline
\end{tabular}

Perhitungan Harga jual perahu berdasarkan perhitungan dari biaya total produksi ditambah $10 \%$ dari biaya pembelian material dan upah (sebesar Rp.12.710.000,-).

Selanjutnya pada tabel berikut disajikan perhitungan prbandingan penerimaan, total biaya, keuntungan, R/C, PP (Pay back Periode) dan BEP dari produksi perahu cadik.

Tabel 8.Analisis Finansial Produksi Perahu Cadik Bottom Glass Untuk Wisata Bahari.

\begin{tabular}{|c|l|c|}
\hline No & KETERANGAN & PERAHU \\
\hline 1 & $\begin{array}{l}\text { Penerimaan 10 } \\
\mathrm{x}(12.710 .000) \\
=127.100 .000\end{array}$ & 127.100 .000 \\
\hline 2 & Total Biaya & 121.375 .000 \\
\hline
\end{tabular}

\begin{tabular}{|c|l|r|}
\hline 3 & $\begin{array}{l}\text { Keuntungan Bersih } \\
(1-2)\end{array}$ & 5.725 .000 \\
\hline 4 & R/C (1/2) & 1.04 \\
\hline 5 & PP (54 bulan) & 4.5 tahun \\
\hline 6 & BEP Biaya (Rp.) & 121.417 .526 \\
\hline 7 & BEP/Unit & 9.5 (10) buah \\
\hline
\end{tabular}

Jadi
1. Keuntungan Bersih:

2. R/C:

3. PP (54 Bulan)

4. BEP Biaya (Rp)

5. BEP/Unit
5.725 .000

1.04

4.5 Tahun

121.417 .526

9.5 (10) buah
Dengan asumsi-asumsi:

1. Produksi perahu 10 buah pertahun.

2. Harga jual perahu adalah total biaya produksi + $10 \%$ dari upah dan pembelian material.

\section{SIMPULAN}

\section{Kesimpulan.}

(1).Faktor-faktor yang menentukan besarnya biaya produksi/pembangunan perahu cadik tipe bottom glass untuk wisata bahari antara lain biaya material, perlengkapan kapal,

Peralatan kerja, upah sewa lahan/galangan dan transportasi.

(2).Biaya produksi untuk satu buah perahu dengan ukuran CUNO 8.35 m3 sebesar Rp.11.600.000,dengan harga jual Rp.12.710.000,- dan keuntungan yang diperoleh sebesar Rp.1.110.000,-.

(3).Berdasarkan CUNO biaya produksi perahu cadik tipe bottom glass untuk wisata bahari di Kelurahan Banten sebesar Rp.1.389.221,5.

(4).Usaha pembuatan perahu cadik tipe bottom glass untuk wisata bahari di Kelurahan Banten Kecamatan Kasemen Kota Serang memberikan keuntungan Rp.5.725.000,- per tahun (penjualan tanpa mesin) dengan payback priode selama 4,5 tahun.

\section{Saran.}

Kiranya rencana tahapan penelitian selanjutnya dapat dipertimbangkan untuk disetujui dilaksanakan pada tahun depan.

\section{DAFTAR PUSTAKA}

Marasabessy, A. 2014, Analisis Keretakan dan Metode Perawatan yang Tepat Lambung kapal dibawah Garis Air Berbahan Fiberglass, Tesis Magister Teknik ISTN Jakarta

Marassabessy, A. 2009 , "Disain Kapal Ikan Sederhana Berbahan FRP" , Hasil Penelitian, Bina Widya LPPM UPN "Veteran” Jakarta. 
Biro Klasifikasi Indonesia,1996a. Rules and Regu;ation for the Classification of Ships (Fibreglass Reinforced Plastic Ships), Jakarta.

Dauri, R, Kebijakan Penerbitan Ijin Kapal Asing di Perairan Zona Ekonomi Eklusif (ZEE), Seminar Nasional,20 Oktober 2001, Penyelenggara HIMASEPA IPB, Jakarta, 9 halaman.

Harbrian,V. 2007."Pengaruh ketebalan inti (Core)terhadap kekuatan bending komposit sandwich serat E-glass Chopped Strand MatUnsaturated Polyester Resin dengan Inti (Core) Spon”, Universitas Negeri Semarang, Semarang

Johan, S. 2011, "Studi Kelayakan Pengembangan Bisnis", ed.1,Graha Ilmu, Yogyakarta.

Kasmir, J. 2012, Studi Kelayakan Bisnis” ed. Rev. cetakan 8,Kencana, Jakarta.

Nurcahyadi, M. 2010, Tekno ekonomi pembuatan perahu fiberglass di Desa Cikahuripan Kecamatan Cisolok, Sukabumi, Skripsi, Fakultas Perikanan dan Ilmu Kelautan IPB , Bogor.

Soekarsono, 2002, Fishing Vessel, FakultasTeknologi Kelautan, Universitas Darma Persada, Jakarta.

Sukirno, S (2005) , "Mikro Ekonomi Teori Pengantar" . Rajawali Press Universitas Indonesia , LPFE-UI , Jakarta.

Sastrodiwongso, T. 2002, Kemudi dan Olah Gerak Kapal, Fakultas Teknologi Kelautan, Universitas Darma Persada, Jakarta.

Cisanggarung Putra Mandiri CV, 2010, Galangan kapal Fiberglass,. Laporan hasil perawatan kapal fiberglass. 